\title{
Scenarios for the management of aquatic bird communities and wetland restoration after intensive agricultural land use and extensive land use cover changes in semi-arid territories
}

\author{
Francisco A. Comín, David Moreno, Cesar Pedrocchi
}

\section{Introduction}

Loss of wetlands is common in territories extensively used for agricultural purposes (Montes \& Bifani 1991, Moser et al. 1999, Mitsch \& GosselinK 2007). This loss negatively impacts wetland birds but can also negatively affect human welfare (JoHnson 2001, FletCHER 2003).

Recovery of bird communities requires availability of habitats, both in quantity and quality adequate to the established objectives (FlETCHER \& KOFORD 2002). Several factors are important for successful bird community recovery, ranging from local to watershed scales (WHITED et al. 2000). We analysed birds communities related to habitat characteristics in a territory extensively used for irrigated agriculture and discuss recommended changes in wetland management for different land use changes at the landscape scale.

Key words: agriculture, birds, irrigation, scenarios, semi-arid, wetlands

\section{Material and methods}

The River Flumen catchment is a $1564 \mathrm{~km}^{2}$ watershed in Monegros region, a large semi-arid territory $\left(2700 \mathrm{~km}^{2}\right.$, average annual rainfall $250 \mathrm{~mm}$ ) in northeast Spain (Fig. 1). The area is subjected to extensive agricultural irrigation $\left(720 \mathrm{~km}^{2}\right)$, identified as sprinkler irrigation at $8-10 \%$ of the total irrigated agricultural area in Monegros $\left(1724 \mathrm{~km}^{2}\right)$ per year. Wetland characteristics, including birds, were studied in 15 small subcatchments (small valleys locally called "vales") of the River Flumen catchment, including all vales with wetlands larger than 1 ha ( 8 wetlands) plus an additional 7 wetlands.

Areas of the 15 wetlands ranged between 0.89 and 3.09 ha and represent $1.89-3.38 \%$ of their respective sub-watersheds in the River Flumen watershed; collectively they occupy 20 ha $(1.3 \%$ of the total River Flumen watershed where they are located). Bird censuses were performed by direct observation with binoculars and by ear in all the studied wetlands during

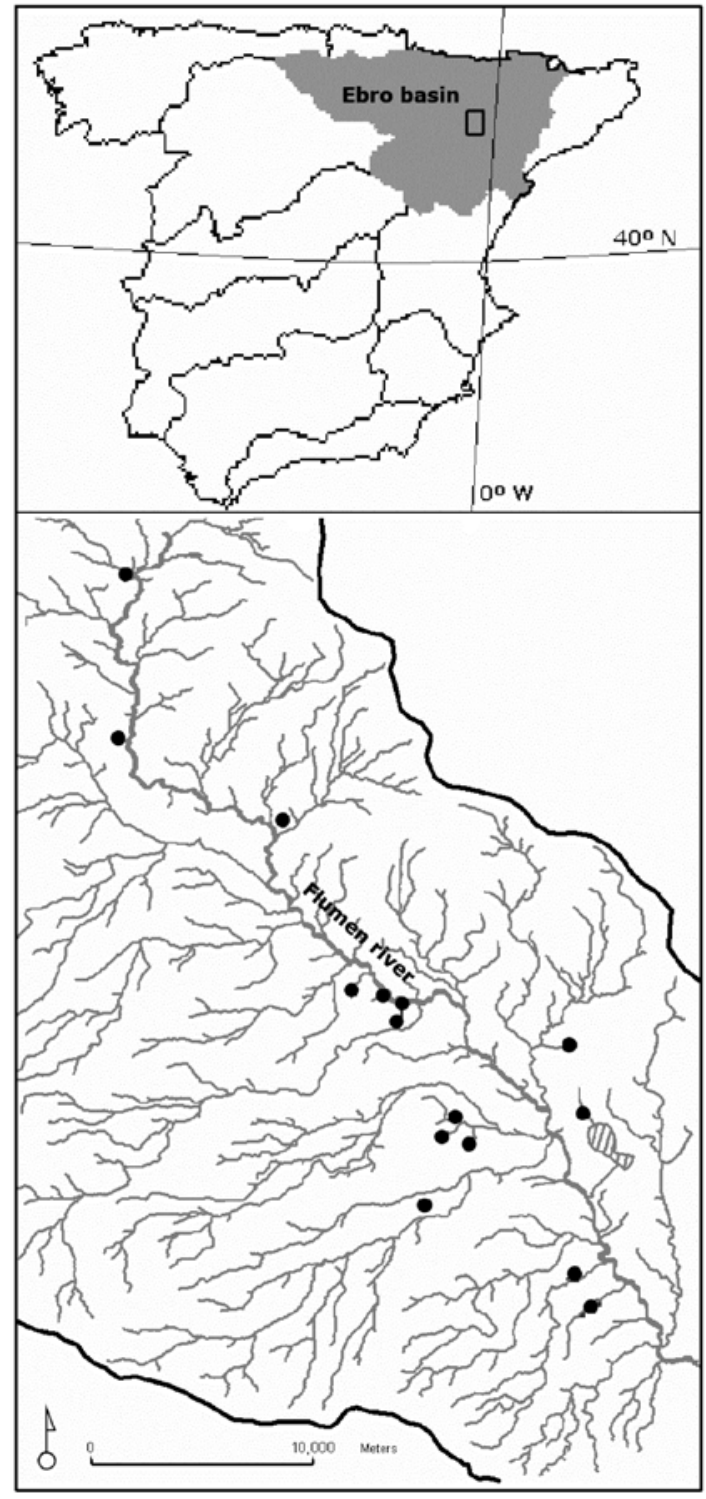

Fig. 1. Ebro River watershed study area and location of the studied wetlands. 
Table 1. List of breeding species in different types of wetlands observed in the study area

\begin{tabular}{|c|c|c|c|c|}
\hline Common name & Latin name & $\begin{array}{l}\text { Deep open water } \\
\text { wetlands }\end{array}$ & $\begin{array}{l}\text { Shallow open } \\
\text { water and mosaic } \\
\text { vegetation }\end{array}$ & $\begin{array}{l}\text { Shallow waters } \\
\text { homogeneously plant } \\
\text { covered wetlands }\end{array}$ \\
\hline Reed warbler & Acrocephalus scirpaceus & $\mathrm{X}$ & $\mathrm{X}$ & $\mathrm{X}$ \\
\hline Great reed warbler & A. arundinaceus & $\mathrm{X}$ & $\mathrm{X}$ & $\mathrm{X}$ \\
\hline Fan-tailed warbler & Cisticola juncidis & $\mathrm{X}$ & $\mathrm{X}$ & $\mathrm{X}$ \\
\hline Penduline tit & Remiz pendulinus & $\mathrm{X}$ & $\mathrm{X}$ & \\
\hline Marsh harrier & Circus aeruginosus & $\mathrm{X}$ & $\mathrm{X}$ & $X$ \\
\hline Water rail & Rallus acuaticus & $\mathrm{X}$ & $\mathrm{X}$ & $\mathrm{X}$ \\
\hline Cetti's warbler & Cettia cetti & $\mathrm{X}$ & $\mathrm{X}$ & \\
\hline Nightingale & Luscinia megarhynchos & $\mathrm{X}$ & $\mathrm{X}$ & \\
\hline Common moorhen & Gallinula chloropus & $\mathrm{X}$ & $\mathrm{X}$ & \\
\hline Mallard & Anas platyrhynchos & $\mathrm{X}$ & $\mathrm{X}$ & \\
\hline Purple heron & Ardea purpurea & X & & \\
\hline Reed bunting & Emberiza schoeniclus & $\mathrm{X}$ & & \\
\hline Moustached warbler & Accrocephalus melanophogon & $\mathrm{X}$ & & \\
\hline European bittern & Botaurus stellaris & $\mathrm{X}$ & & \\
\hline Purple swamp-hen & Porphyrio porphyrio & $\mathrm{X}$ & & \\
\hline Bearded tit & Panurus biarmicus & $X$ & & \\
\hline
\end{tabular}

Table 2. Results of the backward stepwise multiple linear regression relating environmental variables and bird community variables.

\begin{tabular}{lllll}
\hline Dependent variable & Model $\mathrm{r}^{2}$ & Explanatory variable & Partial correlation & Significance $^{\mathrm{a}}$ \\
\hline Richness & 0.952 & Bush & 0.922 & $* * *$ \\
& & Height & 0.816 & $* *$ \\
& & Heterogeneity & 0.733 & $*$ \\
& & Density & 0.696 & $*$ \\
\hline Diversity & Biomass & 0.692 & $*$ \\
& & Distance 1 & -0.661 & $*$ \\
\hline
\end{tabular}

a $* \mathrm{p}<0.05 ; * * \mathrm{p}<0.01 ; * * * \mathrm{p}<0.001$

spring 2004, 2005, and 2006. Wetlands characteristics were measured in situ and those of their watersheds from aerial photographs. A multiple linear regression (MLR) analysis with backward procedure was performed with environmental predictive variables, obtained from a previous principal component analysis (MORENo et al. in press) and bird species densities estimated from the censuses. The MLR analysis allows examining the relationships between environmental variables and each bird community variable separately. Backward procedure allows detecting which environmental variables were most significant to the model.

\section{Results and discussion}

The types of bird communities observed were related to the type of wetland (Table 1). In the study are, type 1 bird community is present only in Sariñena Lake, a 233 ha,
$2.3 \mathrm{~m}$ deep freshwater eutrophic lake that was formerly a shallow, fluctuating saline lake. Type 2 is a relatively diverse bird community distinguished by the presence of a variety of species, including strictly aquatic birds (mallard and common moorhen) that live in wetlands with a relatively heterogeneous plant coverage ( $>5 \%$ of the wetland area is not occupied by the dominant species). Type 3 bird community is present in wetlands "fully" covered by a very dense homogeneous type or emergent macrophytic vegetation (mostly Phragmites australis). This community is comprised of generalist species that require wetland habitat but not necessarily the presence of water.

The major wetland characteristics related with the abundances of bird species are heterogeneous plant coverage, development of the plant community, and distance to a relatively large wetland (Table 2), key factors regulat- 

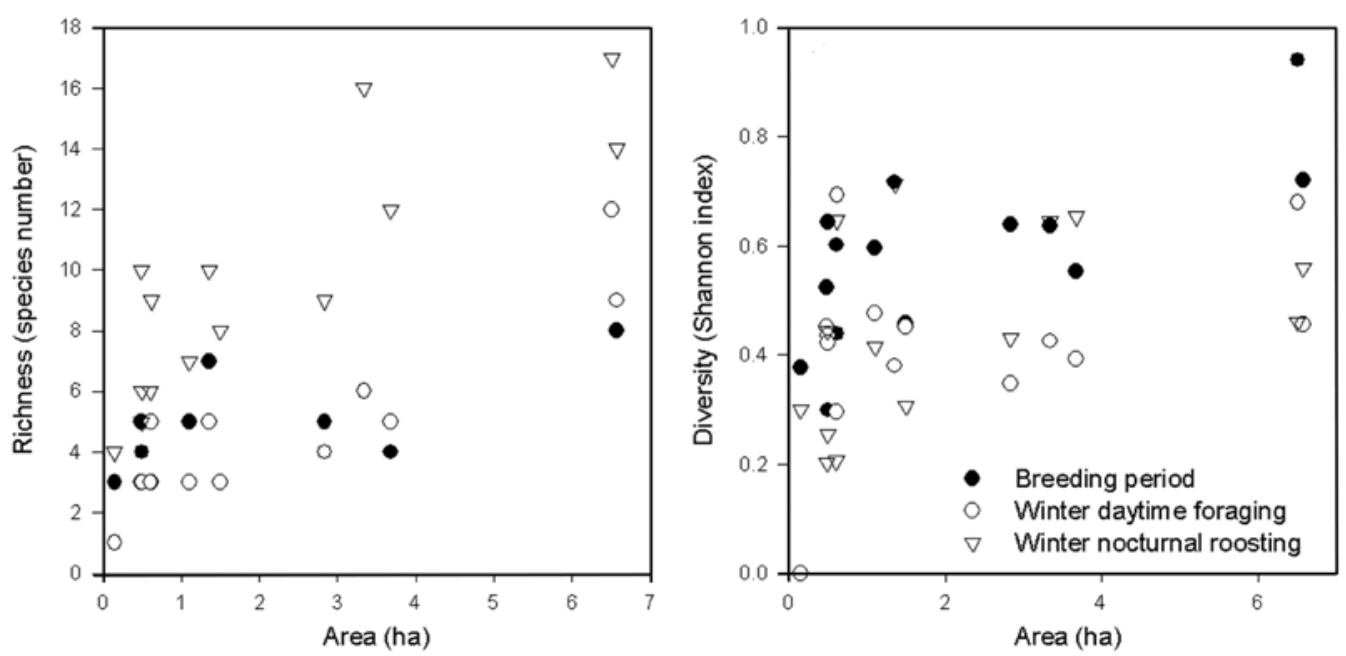

Fig. 2. Bird community characteristics (richness, left; diversity, right) related to wetland area in small valleys (vales) of River Flumen watershed.

ing bird richness and composition in different ecosystems (AUSTEN et al. 2001). In our study area, only wetlands with an area larger than approximately 1 ha hosted significant bird communities (Fig. 2). A large wetland can be a dispersion point for birds in other wetlands; however, dense and homogeneous plant coverage restricts the number and variety of bird species (Comin et al. 2001), as is the case for type 3 bird community.

A rich complex bird community is linked to the presence of different types of habitats in an ecosystem/territory (FLETCHER \& KOFORD 2002); therefore, recovery of habitat diversity is a key step to recover impoverished aquatic birds communities. In our study area, the presence of deep permanent water bodies would increase both the bird number and the number of bird species because a higher variety of habitats would become available. However, restored or constructed deep wetlands may cause more disadvantages than benefits because they would easily become eutrophic after receiving agricultural wastewaters, as in Sariñena Lake in our study area and in other lakes in semi-arid regions (PEDRocchi 1998, SHUFORD et al. 2004).

Different scenarios can be drafted to compare effects on wetlands-associated bird communities. We selected 2 major forcing functions as the drivers to define these scenarios: agricultural transformations and wetlands management. These major forcing functions will determine landscape changes in the near future in many semiarid and arid territories around the world because of increasing demand for food production and life system maintenance as well as improvement of natural systems (SAiko \& Tonn 2000, Geist \& Lambin 2004). Agricultural transformations can occur by increasing the area irrigat- ed by land flooding, which has been the most common method until now, or by changing from flooding to irrigation by sprinkler, which results in much less water use per hectare. The alternative for the present management of wetlands, which are out of control and receive nontreated agricultural wastewater, is to restore wetlands to improve their structures and functions, including those at landscape scale. Establishing an array of wetlands in the territory will provide roosting and breeding facilities for a diverse bird community (Moreno et al. 2007, Moreno et al. in press).

Several scenarios arise from the potential changes of these forcing functions (Table 3): Scenario 0 is the current situation described above. This business-as-usual scenario will take the study area into a homogenised landscape with a fragmented distribution of wetlands zones. These wetlands will have a low water quality (Moreno et al. 2007) and insufficient open water areas to maintain a valuable bird community, and will evolve toward common reed dominated areas with much lower bird diversity (MORENo et al. in press). Scenario 1 is defined as an increase of agriculture area irrigated by canal flood with no changes in wetland management. In this situation, a high amount of agricultural wastewater will drain via surface canals and groundwater into the existing and newly created wetlands. A few wetlands will increase in area; however, these wetlands will not add value to the present situation because most will continue as a mosaic of small wetlands dominated by common reed with deficient water quality, low habitat, and a slight increase of bird diversity in the whole territory. Scenario 2 is defined by an increase of sprinkler-irrigated area and no changes in wetland management. In this scenario, the 
Table. 3. Wetland and bird community outcomes from different scenarios related to wetland management and agricultural irrigation alternatives in the study area.

\begin{tabular}{|c|c|c|}
\hline & Increased sprinkler irrigation & Increased canal irrigation \\
\hline $\begin{array}{l}\text { Decreased wetland } \\
\text { management }\end{array}$ & $\begin{array}{l}\text { 2. Decreased number and area of wetlands. } \\
\text { Increase number of homogeneous common } \\
\text { reed wetlands. Decreased diversity of bird } \\
\text { community. }\end{array}$ & $\begin{array}{l}\text { 1. Increased number of small wetlands. A few } \\
\text { larger wetlands. Decrease water quality. Homo- } \\
\text { geneous reed bird diversity. Non significant } \\
\text { increase of bird diversity. }\end{array}$ \\
\hline $\begin{array}{l}\text { Increased wetland } \\
\text { management }\end{array}$ & $\begin{array}{l}\text { 3. Decrease water run-off and lixiviation. } \\
\text { Wetland fragmentation. Increase habitat } \\
\text { diversity at wetland scale. Less bird numbers } \\
\text { and diversity because of habitat fragmentation. }\end{array}$ & $\begin{array}{l}\text { 4. Increasing water run-off and lixiviation. } \\
\text { Increased wetland number and area. Increasing } \\
\text { bird community. } \\
\text { Sustainable water and land use is not achieved. }\end{array}$ \\
\hline
\end{tabular}

amount of water draining into the wetlands will decrease as well as wetland area. In addition, common reed will expand in the existing wetlands because of the competitive advantages of Phragmites australis under lack of surface water and increased salinity (LISSNER et al. 1999). Consequently, bird communities will become homogenic, dominated by reed birds. This decrease of water use per hectare may be compensated by an increase in sprinklerirrigated area, which may balance the water amount required for wetlands to maintain water flows, levels, and habitat heterogeneity.

In scenarios 3 and 4, active wetland management proceeds, and existing wetlands are restored to provide habitat facilities for bird community development in a diverse way. If agriculture irrigation proceeds by canal flood (scenario 4), the increasing amount of water used will contribute to the establishment of larger wetlands with a mosaic of habitats. However, water quality may not improve because the water outflowing irrigated land in this area is wastewater with high amounts of dissolved salts, nutrients, and pesticides (Isidoro \& ARAGÜEs 2007, Moreno et al. 2007). If sprinkler irrigation takes place (scenario 3), a reduction of the water inputs into the wetlands and, consequently, increased salinity will take place by excess of evapotranspiration in the wetlands. In these last 2 cases, a decrease of adequate habitat area and quality for birds will take place. Restoration actions will be necessary to take into account both habitat diversification and water quality improvement if bird communities are going to improve both in number and diversity.

Another scenario is necessary for rich and diverse bird communities to develop, one that scenario requires meeting agricultural demands for efficiently irrigated systems and natural resources conservation. Both can be achieved in semi-arid and arid regions by implementing land-use plans that use less water for irrigation, use agriculture wastewater for wetland restoration, consider the territory as an integrated ecosystem with interactions among their components, and mutually benefit both human and bird communities (Comin et al. 2001, Mitsch et al. 2001). In this new scenario, increasing agricultural irrigation and bird community conservation can develop if a mosaic of wetlands providing diverse habitats for bird is integrated in land use planning. Major guidelines to design this landscape should be to establish a mosaic of wetlands with different habitats (deep and shallow waters, different types of plant cover) and locate most wetlands at a flight distance from a large wetland.

\section{Acknowledgments}

This study was funded by MEC REN2003-03040, DGA-2006PM019 and Comarca Monegros-Huesca.

\section{References}

Austen, M.J.W., C.M. Francis, D.M. Burke \& M.S.W. BradSTREET. 2001. Landscape content and fragmentation effects on forest birds in Southern Ontario. Condor 103: 701-714.

Comin, F.A., J.A. Romero, O. Hernandez \& M. Menendez. 2001. Restoration of wetlands from abandoned rice fields for nutrient removal, and biological community and landscape diversity. Restor. Ecol. 9: 201-208.

Fletcher, R.J. \& R.R. Koford. 2002. Habitat and landscape associations of breeding birds in restored and native grasslands. J. Wildl. Manag. 66: 1011-1022.

FlETCHER, R.J. 2003. Loss of wetlands. How are bird communities affected. American Institute of Biological Sciences (http://www.actionbioscience.org/environment/fletcher.ht$\mathrm{ml}$, accessed on 22 May 2008)

Geist, H.J. \& E.F. Lambin. 2004. Dynamic causalpatterns of desertification. Bioscience 54: 817-829.

IsIDORO, D. \& R. ArAgüEs. 2007. River water quality and irrigated agriculture in the Ebro Basin: An overview. Int. J. Water Resour. Develop. 23: 91-106.

JoHnson, D.H. 2001. Habitat fragmentation effects on birds in grasslands and wetlands: a critique of our knowledge. Gt. Plains Res. 11: 211-231. 
Lissner, J., H.H. Schierup, F.A. Comin \& V. Astorga. 1999. Effect of climate on the salt tolerance of two Phragmites australis populations. Aquat. Bot. 64: 317-333.

Mitsch, W.J., J.W. Day, J.W. William, P.M. Groffman, D.L. Hey, G.W. Randall \& N. Wang. 2001. Reducing nitrogen loading to the Gulf of Mexico from the Mississippi River Basin: Strategies to counter a persistent ecological problem. BioScience 51: 373-387.

Mitsch, W.J. \& J.G. Gosselink. 2007. Wetlands. J. Wiley and Sons, N.Y.

Montes, C. \& P. Bifani. 1991. An ecological and economic analysis of current status of Spanish wetlands. Report for OCDE, P. 144-195. In K. Turner \& T. Jones [eds.]. Wetlands: Market and Information Failures. Earthscan Publications. Londres.

Moreno, D., C. Pedrocchi, F.A. Comin, M. Garcia \& A. CabeZAS. 2007. Creating wetlands for the improvement of water quality and landscape restoration in semi-arid zones degraded by intensive agricultural use. Ecol. Eng. 30: 103111.

Moreno, D., C. Pedrocchi \& F.A. Comin (in press). How wetland features influence the structure of recent bird commu- nities in irrigated agricultural catchments: design and management implications. Biodiversity and Conservation.

Moser, M., C. Prentice \& S. Frazier. 1999. A global overview of wetland loss and degradation. Ramsar Convention (http:// www.ramsar.org/about/about_wetland_loss.htm, accessed on 22 May 2008).

Pedrocchi, C. 1998. Ecología de Los Monegros. La paciencia como estrategia de supervivencia. (Ecology of Monegros. Patience as survival strategy). In Inst. Estud. Altoaragoneses, Huesca.

SAIKo, T.A. \& I.S. Tonn. 2000. Irrigation expansion and dynamics of desertification in the cirum-Aral region of central Asia. Appl. Geogr. 20: 349-367.

Shuford, W.D., N. Warnock \& R.L. McKernan. 2004 Patterns of shorebird use of the Salton Sea and adjacent Imperial Valley, California. Avian Biol. 27: 61-77.

Whited, D., S. Galatowitsch, J.R. Tester, K. Schik, R. Lehtinen \& J. Husveth. 2000. The importance of local and regional factors in predicting effective conservation planning strategies for wetland bird communities in agricultural and urban landscapes. Landsc. Urban Plann. 49: 49-65.

Authors' address: Instituto Pirenaico Ecología-CSIC. Avda. Reg. Galicia s/n. 22700 Jaca, Huesca, Spain. E-mail: comin@ipe. csic.es 